\title{
PARTICULARITIES OF GREY ALDER (ALNUS INCANA) STANDS IN RIPARIAN GALLERIES ALONG STREAMS OF THE SOUTHERN TRANSYLVANIAN TABLELAND (ROMANIA)
}

Erika SCHNEIDER-BINDER *

\begin{abstract}
* Karlsruhe Institute for Technology - University of Land Baden-Württemberg and Research Center of the Helmholtz Society, Institute for Geography and Geoecology, Department Auen-Institut/Institute for Wetlands Ecology, Josefstrasse 1, Rastatt, Germany, D-76437/“Lucian Blaga” University of Sibiu, Faculty of Sciences, Dr. Ion Raţiu Street 5-7, Sibiu, Sibiu County, Romania, RO-550012, erika.schb@tonline.de, erika.schneider@kit.partner.edu
\end{abstract}

DOI: 10.2478/trser-2019-0010

KEYWORDS: alluvial forests, sub-montane streams, habitat type 91E0, subtype Alnion incanae, Târnava Mare River basin.

\section{ABSTRACT}

Grey Alder (Alnus incana (L.) Moench.) stands are distributed in the Carpathian area on alluvial deposits with sediments of different grain size as galleries along rivers and streams of the sub-montane to the middle montane level. The geological structure (Tertiary sedimentary deposits) in relation to the hydromorphological processes is the base for the structure of the stream valleys, which are in part very deep. Under the special microclimate of these deeper stream stretches with lower temperatures there are favourable conditions for the development of grey alder stands.

ZUSAMMENFASSUNG: Merkmale der Grauerlen- (Alnus incana) Bestände in den Galeriewäldern entlang der Bäche des Süd-Siebenbürgischen Hochlandes.

Bestände der Grauerle (Alnus incana (L.) Moench.) sind in den Karpaten, einschließlich das Hochland von Siebenbürgen auf alluvialen Ablagerungen unterschiedlicher Korngröße von der submontanen bis zur mittleren montanen Stufe als Galerien entlang der Flüsse und Bäche verbreitet. Die geologische Struktur (Tertiäre Ablagerungen) bildet in enger Verbindung mit den hydromorphologischen Prozessen die Voraussetzung für die Form der teils tief eingeschnittenen Bachtäler. Unter den mikroklimatischen Bedingungen dieser Täler finden sich im Hügelland günstige Bedingungen für die Entwicklung von Grauerlenbeständen.

REZUMAT: Caracteristicile galeriilor ripariene cu arin alb (Alnus incana) din sudul Podișului Transilvaniei.

Grupări de arin alb (Alnus incana (L.) Moench.) sunt răspândite în aria Carpaților pe depozite aluviale de diferite fracțiuni granulometrice sub formă de galerii de-a lungul râurilor și pârâurilor din etajul submontan până în cel montan mijlociu. Structura geologică (depozite de sedimente terțiare) constituie în relație cu procesele hidro-morfologice baza pentru forma văilor pârâurilor, pe porțiuni adânc săpate în straturile de sedimente. In condițiile particulare microclimatice cu temperaturi mai scăzute ale acestor segmente de râu există condiții favorabile pentru dezvoltarea grupărilor de arin alb în perimetrul podișului. 


\section{INTRODUCTION}

Grey alder (Alnus incana (L.) Moench.) stands are distributed in the Carpathian area on alluvial deposits of different sediment grain size as galleries along rivers and streams of the sub-montane to the middle montane level, their optimum being at the level of beech and beechfir forests (Georgescu, 1952; Ciocârlan, 2009). But they can also be observed at lower altitude in the Tertiary Tableland or Highland of Transylvania. In some valleys such as those of the rivers Mureș and the Someș, they descend as far as the plains. Sites with Grey alder in the plain are mentioned from Criș, Argeș and Ialomița valleys (Georgescu, 1952). Generally Grey alder occurs on seeping wet or temporary flooded areas, alkaline and nutrient-rich, mostly calcareous, loose and aerated, raw, gravelly-sandy clay soils and slumping marls (Oberdorfer, 2001). Such sites are characteristic also for Carpathian Basin i.e. the Transylvanian Highlands.

The Southern Transylvanian Tableland is characterised by a large network of small streams, tributaries to the larger rivers crossing the tableland, all of them under a higher or lower human impact. The small streams have in common that their springs are situated in the Tertiary Highlands, the riverbeds have a natural or nearly natural structure; the streams are crossing various geological layers of sandstone, marl, clay and loam. Due to this fact the size of sediments in the stream bed are highly variable, from fine clay, loamy and sandy sediments to those with gravel or larger stony materials. The discharge is generally very low, but during high floods, raised by heavy rain falls, they can have a high discharge, accompanied by pronounced hydro-morphological dynamics with erosion and deposition processes. Depending on the crossed layers, the erosion can be different from stretch to stretch in the course of the river. (Roşu, 1980; Posea et al., 1982; Badea et al., 1983; Ielenicz, 1999; Dobros, 2005; Drăgulescu, 2005; Mountford and Akeroyd, 2005; Curtean-Bănăduc, 2005)

On the streams and streamlets exists in the whole Southern Transylvanian Tableland mostly well-structured gallery-like softwood forests with characteristic species such as White willow (Salix alba) and Crack willow (Salix fragilis) adapted to the high humidity of the river banks and the changing water levels. Black alder (Alnus glutinosa) occurs infrequently and generally with low abundance dominance values. The gallery-like softwood stands of the tableland are all included in the priority habitat type 91E0 *Alluvial forests with Alnus glutinosa and Fraxinus excelsior (Alno-Padion, Alnion incanae, Salicion albae) (EUR 28, Gafta and Mountford, 2008) (Fig. 1). From the phytocoenolocical point of view the grey alder stands are included in the association Alnetum incanae Lüdi 1921 taking part of the Class Querco-Fagetea Br.-Bl. Et Vlieg. 37 em., order Fagetalia sylvaticae Pawlowski in Pawlowski, Sokolowski et Wallisch 1928, Alliance Alno-Ulmion Br.-Bl et Tx. 1943 (Syn. Alno-Padion Knapp 1948), sub-alliance Alnenion glutinoso-incanae (Oberdorfer, 1992). The grey alder stands of lower altitude in the submontane area and descending to the colline level, as mentioned for large parts of Europe (Schwabe, 1985; Oberdorfer, 1992), are similar to those of the Transylvanian Tableland.

The present study deals with the occurrences of grey alder (Alnus incana) stands in the Southern part of the Transylvanian Tableland, i.e. from a part of the tableland, situated on the left river bank of the Târnava Mare River, in particular from the Natura 2000 site "SighișoaraTârnava Mare”. On stretches of some tributary streams and streamlets such as the ŞapartocAlbești, V. Dăii, V. Robului upstream of Sighișoara, Şaeș at Sighișoara and Criș, Laslea/Roandola, as well as Valchid downstream of the municipality of Sighişoara, particular sites with grey alder (Alnus incana) can be found. The site conditions and ecological factors for their occurrence were scarcely studied and are remarkable for the tableland conditions. 
From montane, submontane and colline wet river and stream valleys of Romania is described the association Telekio speciosae-Alnetum incanae Coldea (1986) 1990 with the characteristic species Telekia speciosa and Alnus incana and as accompanying species, among others, Impatiens noli-tangere, Circaea lutetiana, Festuca gigantea, Rubus caesius, Stachys sylvatica, Euphorbia amygdaloides, Salvia glutinosa, Scrophularia nodosa, Brachypodium sylvaticum and Cornus sanguineus, most existing as well on the sites with Alnus incana of our study area. The special conditions for the occurrence of grey alder at low altitude arises in general due to the structure of valleys, the content of calcareous substrate (calcareous marl) and the cold air accumulation in the deeper valleys (Oberdorfer, 1992).

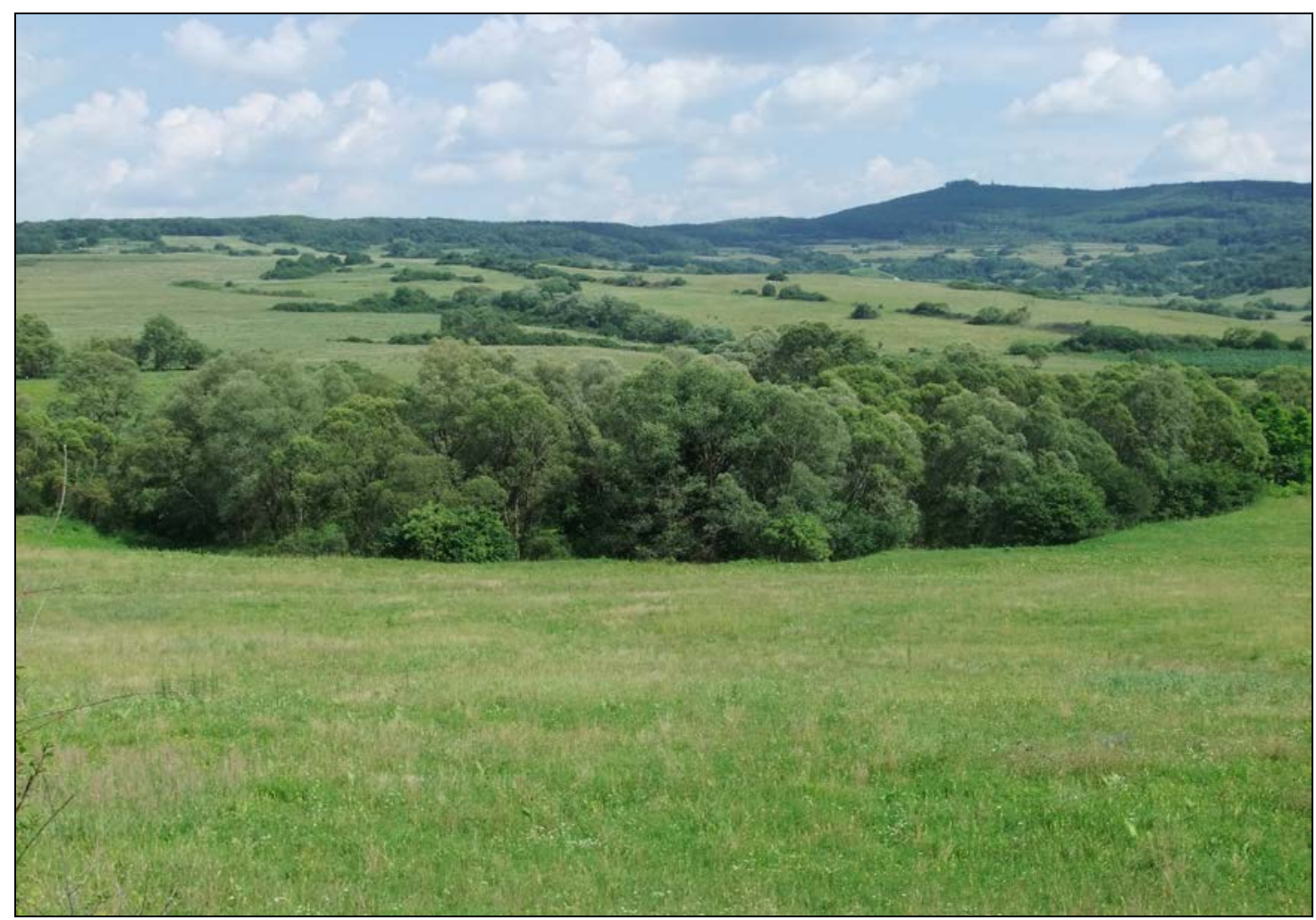

Figure 1: Riparian gallery forest of white and brittle willow (Salix alba and Salix fragilis) on the Șaeș Stream (Schaaserbach) between Daia (Denndorf) and Apold (Trappold) July 2013.

\section{MATERIAL AND METHODS}

During the vegetation periods of the years 2011-2017 field studies concerning the riparian habitats, in particular of the priority habitat type alluvial forests with Alnus glutinosa and Fraxinus excelsior (Alno-Padion, Alnion incanae, Salicion albae) were carried out on different streams of the Southern Transylvanian Tableland. Samples were taken according to the method of Braun-Blanquet with the seven degree abundance-dominance scale (BraunBlanquet, 1964; Borza and Boşcaiu, 1965). The samples were used for detailed studies concerning the ecology, species composition and structure of the phytocoenoses. Special attention was given to the subtype 44.2 Alnioin incanae in strong relation with the subtype 44.13 Salicion albae, and the accompanying tall herbaceous vegetation on the fringe of the riparian galleries. Considered too were aspects concerning the structure of the habitats in 
strong relation with the water dynamics, the grain size of sediments and the succession of the vegetation along ecological gradients from the river banks to the higher elevations of the river valleys. From upstream to downstream along the Târnava Mare River the following tributary valleys have been studied: Șapartoc, Daia, Criș, Laslea/Roandola, and Valchid Valley.

The samples taken are included in phyto-coenological tables and grouped according to characteristic species of the phytocoenological units or according to ecological gradients and presented as well in the context of the European Union habitats (Gafta and Mountford, 2008; EUR28, 2013). The indicator values for light requirements of the species, wetness (W/F) and nitrogen $(\mathrm{N})$ are included as well in the table according to Ellenberg et al. (2001). The nomenclature of species is given according to Sârbu et al. (2013) and Ciocârlan (2009).

\section{RESULTS AND DISCUSSION}

The occurrence of grey alder (Alnus incana) stands is in strong relation to the geomorphological structure of the Tertiary tableland and the hydro-morphological processes. The different layers are build by lime-rich marl, clay, sandstone and conglomerates. Over long time erosion and deposition processes there result different structured valleys with various depth and grain sized sediment materials transported during high floods. In deeper valley stretches an accumulation of cold air creates special microclimate conditions which allow the development of small grey alder galleries at low altitude, similar to those of the Carpathian montane level. Such grey alder galleries similar to those of the study area are mentioned also from other parts of Europe as well under conditions of cold air accumulation (Oberdorfer, 1992; Schwabe, 1995). These galleries with transition character or typical characteristics of montane grey alder galleries are interlocked with tall herbaceous fringe communities (habitat type 6430 Hydrophilous tall herb fringe communities of plains and of montane to alpine levels, EUR 28). The fringe communities occurring in the area are build by species with a transition character from hilly to submontane and montane, or they have typical montane character. The montane species are represented mostly by Petasites hybridus, Telekia speciosa, and Salvia glutinosa and other characteristic species of wet sites. Generally, the hills between 350 and $500 \mathrm{~m}$ in height present in the study area a vegetation including many montane elements, which give the vegetation of the area a transition character from lower tableland hills to those of the submontane and montane level.

On some stretches of the tributaries of the Târnava Mare River in the area of the Natura 2000 site Sighișoara-Târnava Mare, where the valley due to the changing morphological structure of the underground is deeper, as on the stretches dominated by willows, typical sites of grey alder have been registered and monitored. These riparian sites are strongly interlocked with the galleries dominated by white and crack willow and are located in the valleys of Șapartoc-Albești, Saeș, Criș, Laslea, Roandola, and Valchid (Fig. 2; Tab. 1).

The grey alder (Alnus incana) as a characteristic stand-building species is accompanied by white willow (Salix alba) and crack willow (Salix fragilis), both present with high constancy (IV). Their presence is characteristic for these small grey alder galleries at the submontane and hills level of the Southern Transylvanian Tableland. The most characteristic species of the herbaceous layer of these alder stands are the tall herbaceous species Telekia speciosa, Equisetum telmateia, Petasites hybridus and Salvia glutinosa, which generally are present mostly as belts along streams at the level of beech forests, but by lesser coverage degree of the tree crowns they are part of the inner of the riparian gallery. Together with the above-mentioned species, Cirsium oleraceum characteristic for Calthion and Molinietelia communities is the most constant accompanying species in the herbaceous layer. 
On the bottom level of the herbaceous layer the presence of Chrysosplenium alternifolium, characteristic for riparian forests, with temporary flooding, or seepage areas is remarkable (Ellenberg et al., 2001; Oberdorfer, 2001). The occurrence of Rubus caesius, locally of high abundance-dominance values, indicates that grey alder stands occurs at low altitude only on lime-rich sites as was noted also in grey alder phytocoenoses of Central Europe (Oberdorfer, 1992). Also the presence of elm (Ulmus minor) and oak (Quercus robur) is characteristic for the submontane and hills level of the grey alder stands. The bloodtwig dogwood (Cornus sanguinea) is characteristic as well for the low level grey alder stands and described as the typical Cornus sanguinea-form of the Alnetum incanae in Central Europe (Schwabe, 1985; Oberdorfer, 1992).

The high number of wetness indicator species (values seven and eight) as well as species characteristic for temporary flooded areas $(=)$, underlines the character of the wet habitat along the streams. The number of half shade (values five and six) and half light indicator species (seven), demonstrate that the riparian gallery is more or less small and open with a middle crown degree. The indicator species for nutrient (nitrogen) rich soils (values seven and eight) are corresponding to the conditions of temporarily flooded areas. Only the presence of species such as Arctium lappa, Urtica dioica and Sambucus nigra (value nine) indicate high nutrient content, due to human influence by rubbish deposition on the stream banks.

The constancy of Telekia speciosa and the species combination of the samples was the reason to include the grey alder phytoconoses of the left tributaries of Târnava Mare in the association Telekio speciosae-Alnetum incanae Coldea 1990 (Sanda et al., 2008; Coldea, 2015).

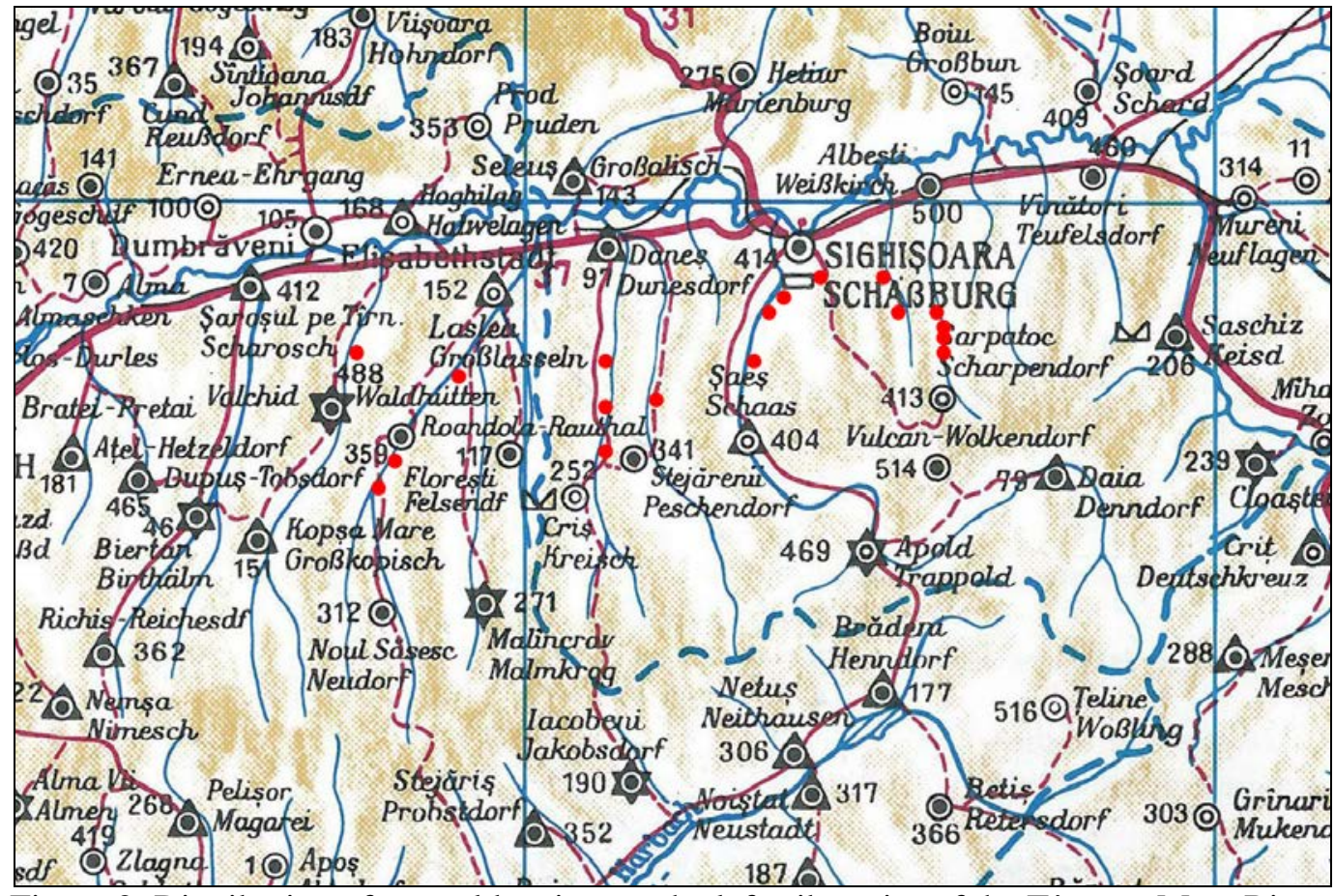

Figure 2: Distribution of grey alder sites on the left tributaries of the Târnava Mare River,

Natura 2000 site Sighișoara/Târnava Mare

(map basis for the distribution points: detail of the map from Fabini, 1999). 
Table 1: Ass. Telekio speciosae-Alnetum incanae Coldea 1990.

\begin{tabular}{|c|c|c|c|c|c|c|c|c|c|c|c|c|c|c|}
\hline & & & Serial number & 1 & 2 & 3 & 4 & 5 & 6 & 7 & 8 & 9 & 10 & \\
\hline & & & $\begin{array}{l}\text { Nr. sample } \\
\text { monitoring } \\
\text { progr. }\end{array}$ & 42 & 43 & 44 & 23 & 17 & 9 & 8 & 12 & E & 7 & \\
\hline & & & Locality & Sa & Sa & $\mathrm{Sa}$ & Sae & $\mathrm{Cr}$ & $\mathrm{Cr}$ & $\mathrm{Cr}$ & $\mathrm{L} / \mathrm{R}$ & Roa & $\mathrm{Va}$ & \\
\hline $\mathrm{L}$ & $\mathrm{U} / \mathrm{W}$ & $\mathrm{N}$ & & & & & & & & & & & & $\mathrm{C}$ \\
\hline & & & Tree layer & & & & & & & & & & & \\
\hline 6 & $7=$ & $\mathrm{x}$ & Alnus incana & 3 & 4 & 3 & 2 & 2 & 1 & 3 & 2 & 3 & 3 & $\mathrm{~V}$ \\
\hline 5 & $8=$ & 7 & Salix alba & . & + & 2 & 3 & 2 & 3 & 2 & 2 & 1 & 2 & $\mathrm{~V}$ \\
\hline 5 & $8=$ & 6 & Salix fragilis & + & + & + & . & 3 & 3 & 1 & 1 & 2 & . & IV \\
\hline 5 & $9=$ & $\mathrm{x}$ & $\begin{array}{l}\text { Alnus } \\
\text { glutinosa }\end{array}$ & . & . & 3 & . & . & . & . & 1 & . & . & $\mathrm{I}$ \\
\hline 5 & $\mathrm{x}$ & $\mathrm{x}$ & Ulmus minor & . & . & . & . & . & . & 1 & . & . & 2 & $\mathrm{I}$ \\
\hline 4 & 6 & 7 & $\begin{array}{l}\text { Tilia } \\
\text { platyphyllos }\end{array}$ & . & . & . & 1 & . & . & . & . & . & . & $\mathrm{I}$ \\
\hline 5 & 5 & 6 & $\begin{array}{l}\text { Acer } \\
\text { campestre }\end{array}$ & . & . & . & . & 1 & . & . & . & . & . & $\mathrm{I}$ \\
\hline 5 & 4 & 8 & $\begin{array}{l}\text { Robinia } \\
\text { pseudaccacia }\end{array}$ & . & . & . & . & + & + & . & . & . & 1 & II \\
\hline 5 & 6 & 7 & Juglans regia &. & . & . & . & . & . & . & 1 & . & . & $\mathrm{I}$ \\
\hline 7 & $\mathrm{x}$ & $\mathrm{x}$ & Quercus robur & . & . & . & . & . & . & . & 1 & . & . & $\mathrm{I}$ \\
\hline 4 & $\mathrm{x}$ & 7 & $\begin{array}{l}\text { Fraxinus } \\
\text { excelsior }\end{array}$ & . & . & . & . & . & . & . & 1 & . & . & I \\
\hline 5 & 7 & 6 & Populus alba & . &. & . & . & . & . & . & . & . & 1 & $\mathrm{I}$ \\
\hline & & & Shrubs layer & & & & & & & & & & & \\
\hline 7 & 5 & 9 & $\begin{array}{l}\text { Sambucus } \\
\text { nigra }\end{array}$ & + & + & . & + & . & + & 1 & . & + & + & IV \\
\hline 7 & 5 & $\mathrm{x}$ & $\begin{array}{l}\text { Cornus } \\
\text { sanguinea }\end{array}$ & 3 & . & . & . & 1 & . & 2 & . & 1 & 2 & III \\
\hline 6 & 5 & 5 & $\begin{array}{l}\text { Evonymus } \\
\text { europaea }\end{array}$ & . & . & . & . & + & 1 & 1 & . & 1 & + & III \\
\hline 6 & $\mathrm{x}$ & 7 & Rubus caesius & 1 &. & + & . & 2 & + & & + & 3 & . & III \\
\hline 6 & $7=$ & $\mathrm{x}$ & Alnus incana &. & + & . & . & . &. & . & + & . & + & II \\
\hline 5 & 4 & 3 & $\begin{array}{l}\text { Evonymus } \\
\text { verrucosa } \\
\end{array}$ &. &. & . & . & 3 &. &. & . & 1 & . & $\mathrm{I}$ \\
\hline 5 & $\mathrm{x}$ & $\mathrm{x}$ & Ulmus minor & . &. & . & . & . &. & . & . & . & 1 & $\mathrm{I}$ \\
\hline 8 & $x=$ & $\mathrm{x}$ & Salix purpurea & . & . & 2 & . & . &. &. & . & 1 & . & $\mathrm{I}$ \\
\hline 5 & 6 & 7 & Acer negundo & . & . & . & + & 2 &. & . & . & . & . & $\mathrm{I}$ \\
\hline
\end{tabular}


Table 1 (continued): Ass. Telekio speciosae-Alnetum incanae Coldea 1990.

\begin{tabular}{|c|c|c|c|c|c|c|c|c|c|c|c|c|c|c|}
\hline & & & Serial number & 1 & 2 & 3 & 4 & 5 & 6 & 7 & 8 & 9 & 10 & \\
\hline & & & $\begin{array}{l}\text { Nr. sample } \\
\text { monitoring } \\
\text { progr. }\end{array}$ & 42 & 43 & 44 & 23 & 17 & 9 & 8 & 12 & $\mathrm{E}$ & 7 & \\
\hline & & & Locality & Sa & Sa & Sa & Sae & $\mathrm{Cr}$ & $\mathrm{Cr}$ & $\mathrm{Cr}$ & $\mathrm{L} / \mathrm{R}$ & Roa & $\mathrm{Va}$ & \\
\hline $\mathrm{L}$ & U/W & $\mathrm{N}$ & & & & & & & & & & & & $\mathrm{C}$ \\
\hline & & & $\begin{array}{l}\text { Climbing } \\
\text { plants/liana }\end{array}$ & & & & & & & & & & & \\
\hline 8 & 6 & 9 & $\begin{array}{l}\text { Calystegia } \\
\text { sepium }\end{array}$ & + & . & + & . & + & + & . & + & + & . & III \\
\hline 6 & $8=$ & 8 & $\begin{array}{l}\text { Humulus } \\
\text { lupulus }\end{array}$ & & . & . & . & . & 2 & + & + & + & . & II \\
\hline 7 & $9=$ & 8 & $\begin{array}{l}\text { Echinocystis } \\
\text { lobata }\end{array}$ & . & . & + & . & . & . & + & + & + & . & II \\
\hline 7 & 5 & 7 & $\begin{array}{l}\text { Clematis } \\
\text { vitalba }\end{array}$ & + & . & . & . & . & 1 & . & . & . & . & I \\
\hline 6 & 6 & 6 & Vitis sylvestris & . & . & . & . & . & 1 & . & . & . & 1 & I \\
\hline 6 & $9=$ & 7 & $\begin{array}{l}\text { Cucubalus } \\
\text { baccifer }\end{array}$ & . & . & . & . & . & . & . & + & + & . & I \\
\hline & & & $\begin{array}{l}\text { Tall } \\
\text { herbaceous } \\
\text { layer }\end{array}$ & . & . & . &. & . & . & . & . & . & . & . \\
\hline 5 & 8 & 5 & $\begin{array}{l}\text { Equisetum } \\
\text { telmateia }\end{array}$ & + & . & + & 2 & . & . & . & + & + & + & III \\
\hline 7 & $8=$ & 8 & $\begin{array}{l}\text { Telekia } \\
\text { speciosa }\end{array}$ & 1 & + & . & 1 & 3 & . & . & + & + & . & III \\
\hline 7 & $8=$ & 8 & $\begin{array}{l}\text { Petasites } \\
\text { hybridus }\end{array}$ & + & 3 & . & + & . & . & . & 2 & 1 & . & III \\
\hline 4 & 6 & 7 & $\begin{array}{l}\text { Salvia } \\
\text { glutinosa }\end{array}$ & 2 & 2 & + & . & + & . & . & . & . & . & II \\
\hline 6 & 7 & 5 & $\begin{array}{l}\text { Cirsium } \\
\text { oleraceum }\end{array}$ & + & . & + & + & . & + & + & + & + & . & IV \\
\hline 7 & 8 & 4 & $\begin{array}{l}\text { Angelica } \\
\text { sylvestris }\end{array}$ & + & . & . & + & . & . & + & . & . & . & II \\
\hline 6 & 8 & 4 & $\begin{array}{l}\text { Scirpus } \\
\text { sylvaticus }\end{array}$ & 2 & . & + & + & . & . & . & 3 & . & . & II \\
\hline 7 & 7 & 8 & $\begin{array}{l}\text { Eupatorium } \\
\text { cannabinum }\end{array}$ & + & . & + & + & . & . & . & . & + & . & II \\
\hline 8 & $\mathrm{x}$ & 6 & $\begin{array}{l}\text { Solidago } \\
\text { canadensis }\end{array}$ & . & . & . & + & . & . & + & . & + & + & II \\
\hline 6 & 8 & $\mathrm{x}$ & $\begin{array}{l}\text { Lysimachia } \\
\text { vulgaris }\end{array}$ & + & . & . & . & . & . & . & . & + & . & I \\
\hline 8 & 7 & 6 & $\begin{array}{l}\text { Rudbeckia } \\
\text { laciniata }\end{array}$ & + & . & + & . & 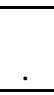 & . & . & 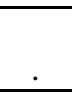 & . & . & I \\
\hline
\end{tabular}


Table 1 (continued): Ass. Telekio speciosae-Alnetum incanae Coldea 1990.

\begin{tabular}{|c|c|c|c|c|c|c|c|c|c|c|c|c|c|c|}
\hline & & & Serial number & 1 & 2 & 3 & 4 & 5 & 6 & 7 & 8 & 9 & 10 & \\
\hline & & & $\begin{array}{l}\text { Nr. sample } \\
\text { monitoring } \\
\text { progr. }\end{array}$ & 42 & 43 & 44 & 23 & 17 & 9 & 8 & 12 & $\mathrm{E}$ & 7 & \\
\hline & & & Locality & Sa & Sa & Sa & Sae & $\mathrm{Cr}$ & $\mathrm{Cr}$ & $\mathrm{Cr}$ & $\mathrm{L} / \mathrm{R}$ & $\begin{array}{c}\text { Ro } \\
\text { a }\end{array}$ & $\mathrm{Va}$ & \\
\hline $\bar{L}$ & $\mathrm{U} / \mathrm{W}$ & $\mathrm{N}$ & & & & & & & & & & & & $\bar{C}$ \\
\hline & & & $\begin{array}{l}\text { Herbaceous } \\
\text { layer }\end{array}$ & & & & & & & & & & & \\
\hline $\mathrm{x}$ & 6 & 9 & Urtica dioica & 2 & . &. & . & + & 3 & + & 3 & + & 2 & IV \\
\hline 5 & 6 & 8 & $\begin{array}{l}\text { Aegopodium } \\
\text { podagraria }\end{array}$ & + & + & . & + & 3 & . & 2 & . & 3 & 3 & IV \\
\hline 7 & $8=$ & 8 & $\begin{array}{l}\text { Myosoton } \\
\text { aquaticum }\end{array}$ & + & . &. & + & + & . & + & . & 1 & . & III \\
\hline 7 & $8=$ & 8 & $\begin{array}{l}\text { Polygonum } \\
\text { hydropiper }\end{array}$ & 2 & + & & . & + & . & + & . & . & . & II \\
\hline 4 & $8=$ & 5 & $\begin{array}{l}\text { Chrysospleniu } \\
\text { m alternif. }\end{array}$ & . & . & . & . & 2 & . & 2 & 2 & . & 3 & II \\
\hline 7 & $9=$ & 7 & $\begin{array}{l}\text { Lycopus } \\
\text { europaeus }\end{array}$ & + & . & + & + & . &. &. & . & . & . & II \\
\hline 3 & 5 & 6 & $\begin{array}{l}\text { Brachypodium } \\
\text { sylvaticum }\end{array}$ & 2 & . & + & . & + & . & . & . & . & . & II \\
\hline 7 & $\mathrm{X}$ & 7 & Elymus repens &. & . & 2 & . & + & . & . & + & + & . & II \\
\hline 7 & $8=$ & 7 & $\begin{array}{l}\text { Mentha } \\
\text { longifolia }\end{array}$ & . & . & + & + & . &. & + & . & . & . & II \\
\hline 7 & 8 & 5 & $\begin{array}{l}\text { Myosotis } \\
\text { scorpioides }\end{array}$ & . & . & + & . &. &. & + & . & . & + & II \\
\hline 7 & $9=$ & 7 & Poa palustris & . & . &. & + & . & . & . & + & + & . & II \\
\hline 7 & 7 & 8 & $\begin{array}{l}\text { Symphytum } \\
\text { officinale }\end{array}$ & . & . & . & + & . &. & + & . & + & . & II \\
\hline 6 & 7 & 7 & $\begin{array}{l}\text { Ranunculus } \\
\text { repens }\end{array}$ & . & . & + & + & + &. &. & . & + & . & II \\
\hline 6 & 6 & 7 & $\begin{array}{l}\text { Glecoma } \\
\text { hederacea }\end{array}$ & . & . & . & + & 2 &. & + & + & + & + & III \\
\hline 4 & 6 & 7 & $\begin{array}{l}\text { Stachys } \\
\text { sylvatica }\end{array}$ & . & . & . & . & + & + & . & 2 & & . & II \\
\hline 4 & 6 & $\mathrm{x}$ & $\begin{array}{l}\text { Lysimachia } \\
\text { nummularia }\end{array}$ & . & . & . & + & + &. &. & . & + & . & II \\
\hline 7 & 6 & 8 & $\begin{array}{l}\text { Erigeron } \\
\text { annuus }\end{array}$ & + & . & . & + & + & . & . & & & + & II \\
\hline 7 & $\mathrm{X}$ & 8 & $\begin{array}{l}\text { Galium } \\
\text { aparine }\end{array}$ & + & + & . & . & + & . & . & . & + & . & II \\
\hline 7 & 5 & 6 & $\begin{array}{l}\text { Dactylis } \\
\text { glomerata }\end{array}$ & & - & 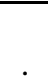 & + & + & 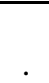 & . & + & + & 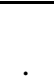 & II \\
\hline
\end{tabular}


Table 1 (continued): Ass. Telekio speciosae-Alnetum incanae Coldea 1990.

\begin{tabular}{|c|c|c|c|c|c|c|c|c|c|c|c|c|c|c|}
\hline & & & Serial number & 1 & 2 & 3 & 4 & 5 & 6 & 7 & 8 & 9 & 10 & \\
\hline & & & $\begin{array}{l}\text { No. sample } \\
\text { monitoring } \\
\text { progr. }\end{array}$ & 42 & 43 & 44 & 23 & 17 & 9 & 8 & 12 & E & 7 & \\
\hline & & & Locality & Sa & Sa & Sa & Sae & $\mathrm{Cr}$ & $\mathrm{Cr}$ & $\mathrm{Cr}$ & $\mathrm{L} / \mathrm{R}$ & $\mathrm{Roa}$ & $\mathrm{Va}$ & \\
\hline $\mathrm{L}$ & $\mathrm{U} / \mathrm{W}$ & $\mathrm{N}$ & & & & & & & & & & & & $\mathrm{C}$ \\
\hline 8 & 4 & 4 & $\begin{array}{c}\text { Melandrium } \\
\text { album }\end{array}$ &. &. &. & + &. & + & & + & + & & II \\
\hline 7 & 5 & 6 & $\begin{array}{c}\text { Galeopsis } \\
\text { tetrahit }\end{array}$ &. &. & + &. & + &. &. &. & + &. & II \\
\hline 7 & 5 & 8 & $\begin{array}{c}\text { Galeopsis } \\
\text { speciosa }\end{array}$ & + &. &. & + & + & + & + &. &. &. & III \\
\hline 9 & 5 & 9 & Arctium lappa & + & + & + & - & + &. &. &. &. &. & II \\
\hline 6 & 5 & 8 & $\begin{array}{c}\text { Chelidonium } \\
\text { majus }\end{array}$ & + & + & + &. &. &. &. &. &. &. & II \\
\hline 7 & 5 & $\mathrm{x}$ & $\begin{array}{c}\text { Prunella } \\
\text { vulgaris }\end{array}$ & + & + &. & + & &. &. &. &. &. & II \\
\hline 4 & 5 & 7 & $\begin{array}{c}\text { Geum } \\
\text { urbanum }\end{array}$ &. &. &. &. & + &. &. & + & + &. & II \\
\hline
\end{tabular}

Names of the localities /streams: Șa $=$ Șapartoc 81, 2, 3, Sae $=$ Șaeș (4), Cr $=$ Criş, L/Roa $=$ between Laslea and Roandola, Roa = Roandola, Va = Valchid;

Data and point of sampling Șa = Şapartoc, 4.07.2013: 4612 40,4 N, 245048.9 and 2 sampling point more in distance of hundred meters in the neighbouring area; Şae = Șaeș 4608435 N, 24 47678 E; Cr = Criș (5): between Daneș and Criș, 13.09.2012: 46200919835379 N, 24704 803985213 (E); Criș (6) downstream the bridge, 13.09.2012; Criș (7): near to the place of number fife on the upstream lying meander; 8. L/Roa = 4610789 N, 02437661 E, alt 371; 9. Roa, two km upstream the village, $4609479 \mathrm{~N}, 02436075 \mathrm{E}, 375 \mathrm{~m}$ altitude; 10. Va = downstream the village, on the right river bank: 14.07.012, 4612786 N, $2436081 \mathrm{E}$.

Species present with + in one sample (constancy I): column 1: Rumex obtusifolius, Arctium minus, Oxalis stricta; column three: Chenopodium album, Juglans regia, Pyrus pyraster, Robinia pseudacacia, Rorippa amphibia, Rosa canina, Salix triandra; column four: Agrimonia eupatoria, Carpinus betulus, Cichorium intybus, Crataegus monogyna, Pulicaria dysenterica, Silene vulgaris; column five: Acer negundo, Asarum europaeum, Corylus avellana, Deschampsia caespitosa, Dipsacus laciniatus, Heracleum sphondylium, Lamium maculatum, Stellaria media; column six: Senecio paludosus; column nine: Ajuga reptans, Carex hirta, Festuca gigantea, Lactuca serriola, Phragmites australis, Stellaria holostea, Thalictrum flavum, Viola odorata.

Species occurring in two samples (constancy I): columns one and three: Bidens tripartita, Geranium phaeum, Holcus lanatus, Lapsana communis, Trifolium repens, Tussilago farfara; column one and six: Agrostis stolonifera; columns two and seven: Xanthium strumarium; columns three and four: Achillea millefolium, Sium latifolium; columns three and six: Juncus effusus; columns four and five: Taraxacum officinale; Columns five and nine: Stachys palustris, Pulmonaria officinalis; columns six and nine: Artemisia vulgaris; columns seven and nine: Lythrum salicaria; columns eight and nine: Vicia cracca. 
Comparing the extent of riparian gallery stretches build by grey alder stands with those dominated by white and brittle willow, the firsts are shorter and more localized in the area with deep valleys and special microclimate conditions. In all studied valleys they have a similar structure and species combination, but there are also some differences from upstream to downstream concerning the structure of the vegetation layers, and the species composition (Tab. 1). These differences of the riparian gallery forest stretches are caused almost by human intervention in longer time through cutting trees, burning, and deposition of garbage (near to the villages). But in comparison with the stretches dominated by willows the stretches with grey alder are in a better and more natural state.

The most extended and representative grey alder galleries in the study area are those of the Șapartoc Valley east of Sighișoara, the most eastern of the monitored valleys. In that area from its source in the surrounding hills of the highland to the mouth of the Sapartoc Stream into the Târnava Mare River can be followed a succession of interlocking phytocoenoses as they are known from canon like deep valleys, constituting forests of ravines (“Schluchtwälder”) with steep stream sides.

The Șapartoc Stream collects its waters from a small spring and seepage waters of the slopes near to the village of Șapartoc. The vegetation of the area is characterized by grasslands developed after forest clearance around the village in the upper part of a beech forest (Fig. 3). In that area many occurred and continue to do so. In the beginning the small water course of the valley crossing the forest have no special riparian wet vegetation, the beech forest with here and there sycamore (Acer pseudoplatanus), ash (Fraxinus excelsior) and largleaved lime (Tilia platyphyllos) reaching to the river bank. Such forests of slopes, screes and ravines are according to the list of habitat types of the FFH-Directive - included in the habitat type 9180 (EUR 28, Gafta and Mountford, 2008).

The typical wet riparian species accompanying the stream through the beech forest are mainly the tall herbaceous Telekia speciosa (Fig. 5), Petasites hybridus and Equisetum telmateia. These species occur together or in separate groups, constituting the first riparian vegetation belt. This is followed by the development of a small grey alder belt, which is broadened to the downstream part (Fig. 3). The tall herbaceous vegetation remains further as a well contoured belt (Figs. 4 and 5), but the species takes part together with other herbaceous species also of the layers of the riparian forest, where the light conditions are appropriate. The most compact herbaceous belt accompanying the stream is that of Petasites hybridus (Fig. 6). Near to the mouth into the Târnava Mare River the riparian gallery of grey alder is changing through a transition area including occurrences of black alder (Alnus glutinosa) disappearing completely on the lowest level of the valley. At the mouth it is replaced by stands of white and crack willows, due to changes in site conditions (Tab. 2). The ravine-like character on the upper and middle stretch is lost due to slopes with smaller inclination on the opening to the Târnava Mare River valley. The succession and the changes in species composition are clearly visible from upstream to downstream. 


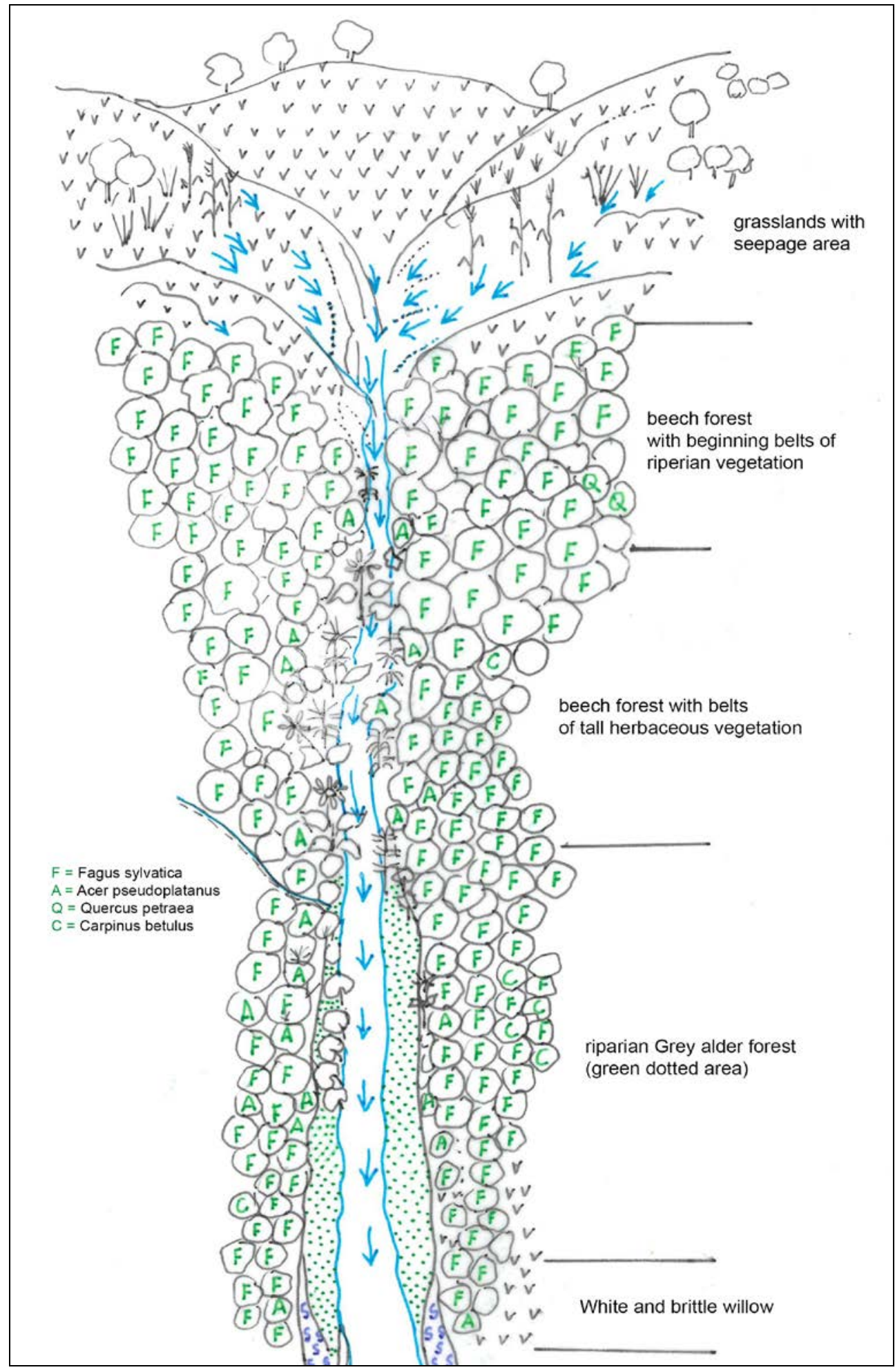

Figure 3: Scheme of the structure and distribution of the vegetation of the Şapartoc Valley with grey alder stands (Natura 2000 site Sighişoara/Târnava Mare). 
Table 2: Succession of the riparian vegetation from upstream to downstream in the Şapartoc Valley (Fig. 3); all the samples included in the table were realized along the Şapartoc Valley from upstream to downstream on 4th July 2013.

\begin{tabular}{|c|c|c|c|c|c|c|c|c|c|c|}
\hline Serial number & 1 & 2 & 3 & 4 & 5 & 6 & 7 & 8 & 9 & 10 \\
\hline Sample no. monitoring & 39 & 40 & $40 \mathrm{a}$ & 41 & 42 & $42 \mathrm{~b}$ & 43 & 44 & 45 & 46 \\
\hline \multicolumn{11}{|c|}{ Tree layer and shrubs shrubs layer } \\
\hline Fagus sylvatica & 2 & 2 & & 2 & . & . & . & . & . & . \\
\hline Acer pseudoplatanus & 2 & 2 & 2 & 2 & . & . & . & . & . & . \\
\hline Acer pseudoplatanus & . &. & & 1 & . & . & . & . & . & . \\
\hline Popus tremula & 1 & 1 & 2 & . & . & . &. & . & . & . \\
\hline Tilia platyphyllos & 1 &. & . & 1 & . & . &. & . & . & . \\
\hline Robinia pseudoacaccia & 1 &. & . & 1 & . & . & . & . & . & . \\
\hline Carpinus betulus & . &. & 1 &. &. & . &. & . & . & . \\
\hline Fraxinus excelsior & . & . & . & 1 & . & . & . & 1 & . & . \\
\hline Acer campestre & . &. & . & . & 1 & + & . & . & . & . \\
\hline Alnus incana & . & . & . & . & 2 & 4 & 4 & 3 & . & . \\
\hline Alnus incana & . &. & . & . & 2 & 2 & + & . & . & . \\
\hline Alnus glutinosa & . & . & . & . & . & . & . & 3 & . & . \\
\hline Salix alba & . &. & . & . & . & . & . & 2 & 2 & + \\
\hline Salix fragilis &. &. & . & + & + & + &. & + & 4 & 3 \\
\hline Salix alba & . &. & . & . & . & . & . & . & + & 2 \\
\hline Salix purpurea &. &. & . &. &. & . &. & 2 &. & + \\
\hline Salix triandra & 1 & . & . & . & . & + & . & + & . & . \\
\hline Corylus avellana & 1 & 2 & 1 & + & . & . & . & . & + & . \\
\hline Cornus sanguinea & . & 1 & & + & 3 & &. & . & + & . \\
\hline Sambucus nigra & . &. & + & + & 1 & 2 & + & + & 2 & + \\
\hline Evonymus europaeus &. &. & & + & & & & + & . & + \\
\hline Robinia pseudaccacia & + &. & + & + & + & . & . & . & + & . \\
\hline Rubus caesius & + &. & 1 & + & + & 2 & + & . & + & . \\
\hline \multicolumn{11}{|l|}{ Climbing plants/lianas } \\
\hline Clematis vitalba & . & + & . & + & + & . & . & + & . & . \\
\hline Calystegia sepium & . &. & . & . & + & . &. & + & + & . \\
\hline Echinocystis lobata &. &. & . & . & . & + &. & + & + & . \\
\hline Humulus lupulus & . &. & 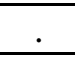 & . & . & . &. & + & 2 & 1 \\
\hline \multicolumn{11}{|l|}{ Tall herbaceous layer } \\
\hline Telekia speciosa & 1 & 3 & 3 & 2 & 1 & 1 & 3 & + &. & . \\
\hline Petasites hybridus & 3 & + & + & 4 & 4 & 3 & + & . & . & . \\
\hline Eqisetum telmateia & 3 & + & 2 & & + & 4 & 3 & . & . & + \\
\hline Salvia glutinosa & 1 & 3 & + & 2 & + & 2 & + & + & . & + \\
\hline Cirsium oleraceum & 2 & + & 3 & . & 2 & + & 2 & + & . & . \\
\hline Scirpus sylvaticus & . & . & + & + & + & . & . & + & + & . \\
\hline Eupatorium cannabinum & + & . & & + & + & 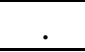 & + & 1 & + & + \\
\hline
\end{tabular}


Table 2 (continued): Succession of the riparian vegetation from upstream to downstream in the Şapartoc Valley (Fig. 3); all the samples included in the table were realized along the Sapartoc Valley from upstream to downstream on 4th July 2013.

\begin{tabular}{|c|c|c|c|c|c|c|c|c|c|c|}
\hline Herbaceous layer & & & & & & & & & & \\
\hline Aegopodium podagraria & . & + & + & + & 1 & 2 & 2 & + & + & \\
\hline Myosoton aquaticum & . & + & + & + & + & 3 & + & . & . & \\
\hline Urtica dioica & . & . & + & 3 & + & + & + & . & . & \\
\hline Brachypodium sylvaticum & . & . & 2 & . & 2 & + & + & . & . & \\
\hline Trifolim repens & . & . & + & . & . & + & . & + & . & . \\
\hline Erigeron annuus & . & . & + & . & 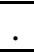 & + & . & + & . & . \\
\hline Arctium lappa & . & . & . & . & + & + & . & . & + & . \\
\hline Chelidonium majus & . & . & . & . & + & + & + & + & . & \\
\hline Galium aparine & . & . & . & . & + & + & . & + & . & \\
\hline Rudbeckia laciniata & . & . & . & . & + & + & + & . & . & . \\
\hline Galeopsis speciosa & . & . & . & . & + & + & . & + & . & \\
\hline Tussilago farfara & . & . & . & $\cdot$ & + & 2 & . & . & . & . \\
\hline Polygonum hydropiper & . & . & . & . & . & + & . & + & . & + \\
\hline Elymus repens & . & . & . & . & . & 2 & + & 2 & + & 2 \\
\hline Artemisia vulgaris & . & . & . & & . & . & . & . & . & 2 \\
\hline
\end{tabular}

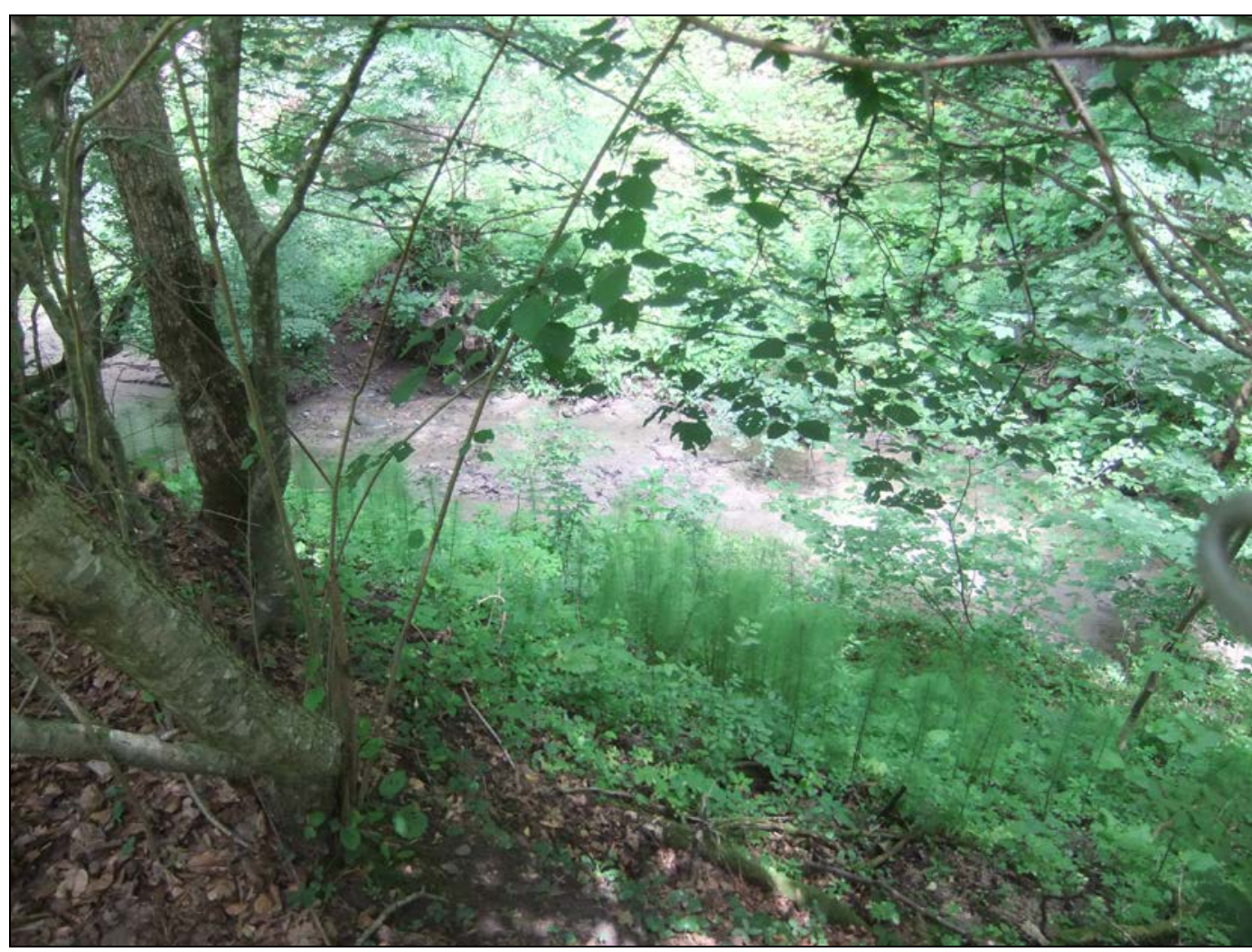

Figure 4: Grey alder phytocoenose with Equisetum telmateia on the upper Șapartoc Stream. 


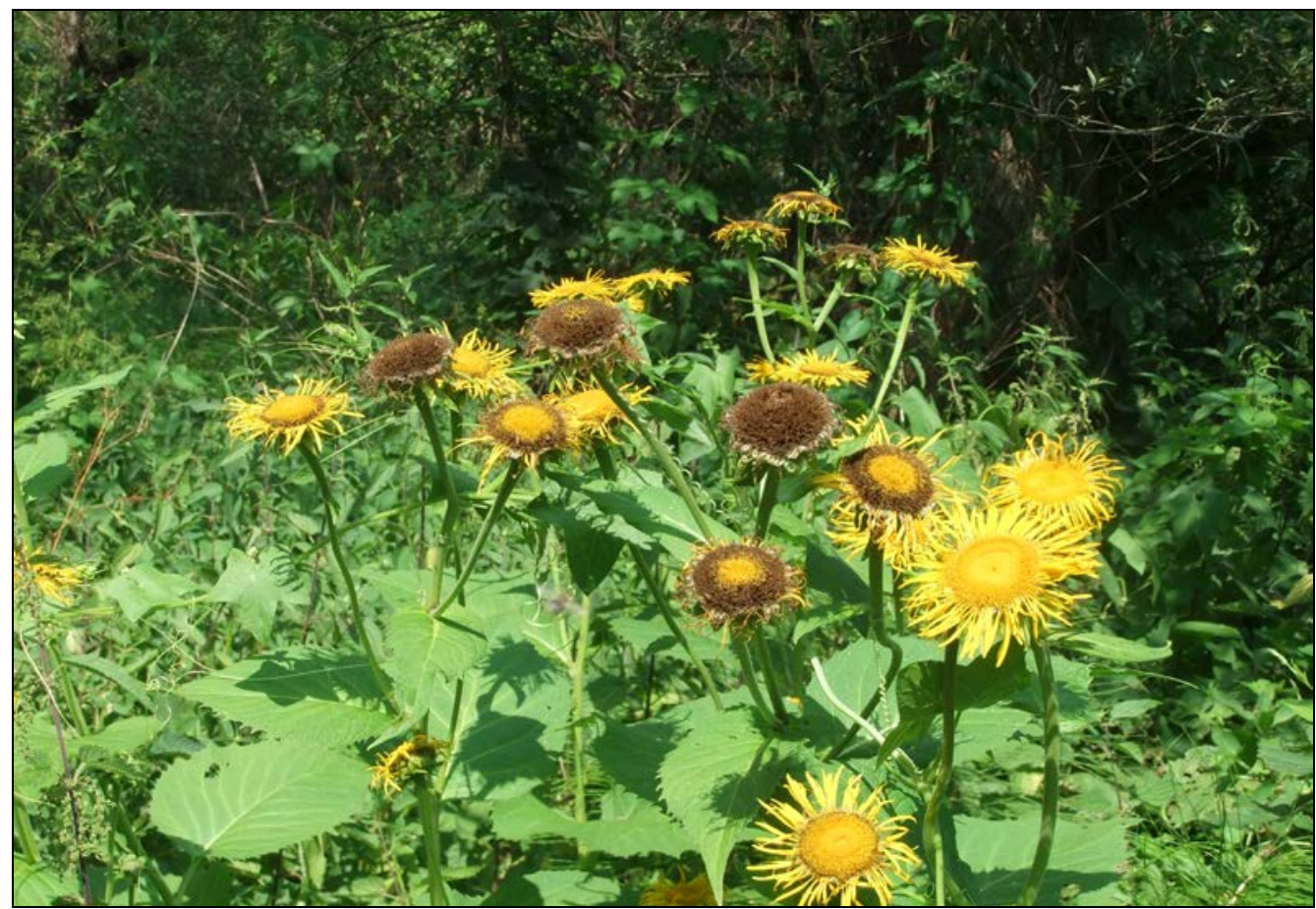

Figure 5: Telekia speciosa on the edge of the grey alder gallery middle Șapartoc Valley.

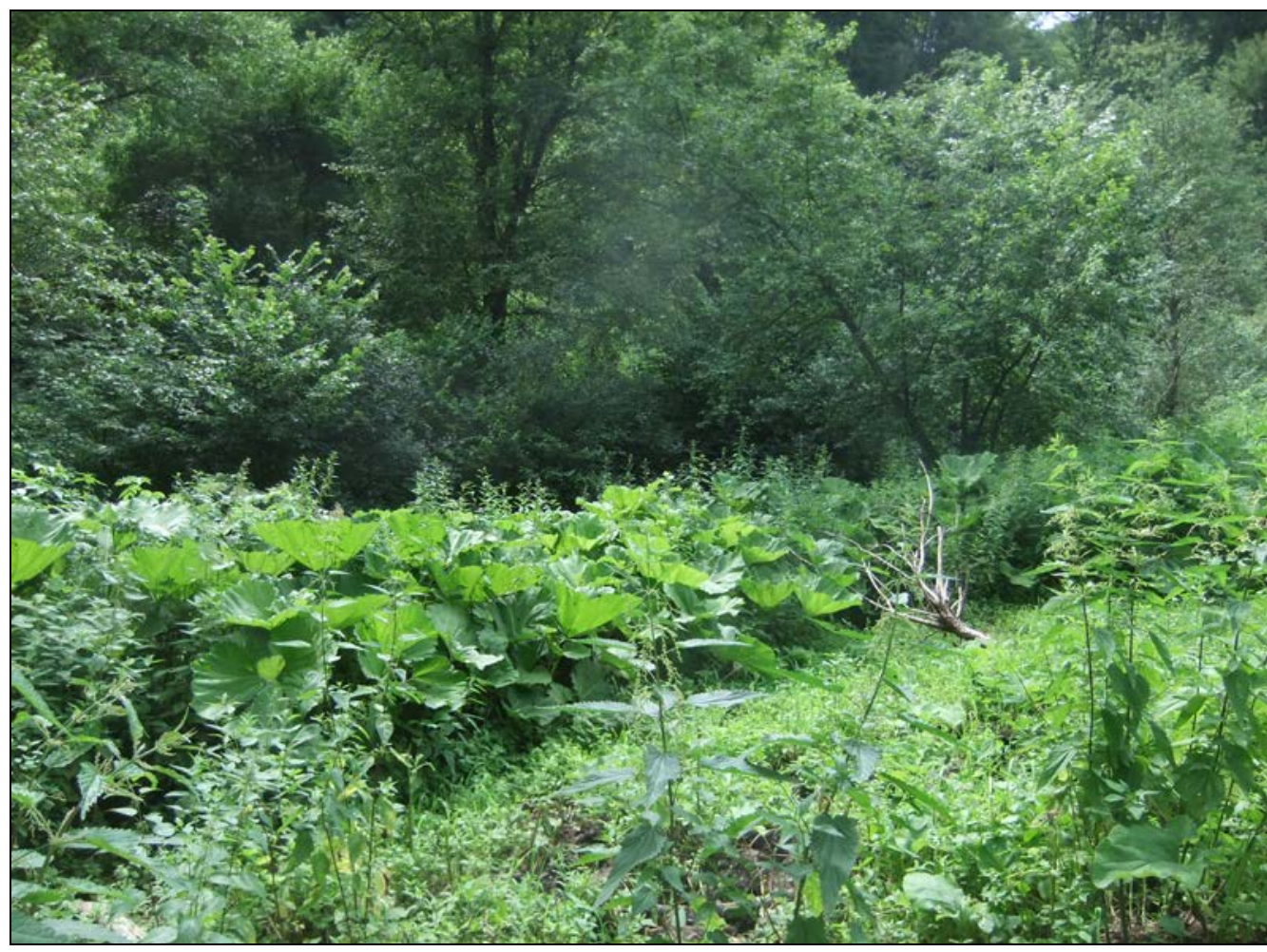

Figure 6: Grey alder gallery in the middle Șapartoc Valley with tall herbaceous belt dominated by Petasites hybridus. 


\section{CONCLUSIONS}

The occurrence of grey alder stands in the southern part of the Transylvanian Tableland is strongly related to the special site conditions given by the geomorphological structure of the deepened streambeds and the accumulation of cold air, which create a special microclimate and special ecological conditions for their existence in the area. These conditions exist generally only on small stretches along the streams. The grey alder stands are strongly interlocked with the larger spread white and crack brittele willow stands, these lasts building characteristic riparian galleries all over the Southern Transylvanian Tableland. Between the characteristic species exists with high constancy tall herbaceous species with a montane distribution area such are Telekia speciosa, Petasites hybridus, Equisetum telmateia, and Salvia glutinosa. These species have their main distribution area on streams of the level of beech forests, descending sometimes on lower altitudes of the submontane and hills level. Due to their rare occurrences under the above-mentioned special site conditions, such grey alder stands - included in the habitat type 91E0 merit more attention in the frame of management plans for Natura 2000 sites with existing grey alder stands. 


\section{ACKNOWLEDGEMENTS}

Sincere thanks are given to Klaus Gross/Nürnberg researcher of the flora of Sighișoara and surrounding area, for additional information concerning the distribution of grey alder. 


\section{REFERENCES}

1. Borza A. and Boşcaiu N., 1965 - Introducere în studiul covorului vegetal, Edit. Academiei Române, București, 340. (in Romanian)

2. Badea L., et al., 1983 - Geografia României I, Geografia Fizică, Edit. Academiei Române, (in Romanian)

3. Braun-Blanquet J., 1964 - Pflanzensoziologie, 3, Auflage, Springer Verlag Wien, 865. (in German)

4. Ciocârlan V., 2009 - Flora ilustrată a României, Pteridophyta et Spermatophyta, Edit. Ceres, Bucureşti, 1141. (in Romanian)

5. Coldea G. (ed.), Indreica A. and Oprea A., 2015 - Les associations végétales de Roumanie, 3, les associations forestières et arbustives. Presa universitară Clujeană, Accent, 281. (in French)

6. Curtean-Bănăduc A., 2005 - Târnava Mare River (Romania) ecological assessment, based on the benthic macroinvertebrates communities, Transylvanian Review of Systematical and Ecological Research, 2, The Târnava River Basin, 109-122.

7. Dobros V., 2005 - Aspects concerning the liquid flow in Târnava Mică River hydrographic basin (Transylvania, Romania), Transylvanian Review of Systematical and Ecological Research, 2, The Târnava River Basin, 1-4.

8. Drăgulescu C., 2005 - The hydrophilous and hygrophilous flora and vegetation of Târnave Rivers (Transylvania, Romania), Transylvanian Review of Systematical and Ecological Research, 2, The Târnava River Basin, 13-30.

9. Ellenberg H., Weber H. E., Düll R., Wirth V. and Werner W., 2002 - Zeigerwerte von Pflanzen in Mitteleuropa/Indicator values of plants in Central Europe, Scripta Geobotanica, 18, 264, Erich Goeltze K. G., Göttingen. (in German)

10. European Commission DG Environment, 2013 - Interpretation manual of European Union habitats- EUR28, 144.

11. Fabini H., 1999 - Atlas der siebenbürgisch-sächsischen Kirchenburgen und Dorfkirchen. Band 1, 2. überabrbeitete Auflage. Monumenta Verlag Hermannstadt und Arbeitskreis für siebenbürgische Lsndeskunde e. V. Heidelberg, 870 und mit Kartenanhang. (in German)

12. Gafta D. and Mountford O., 2008 - Manual de interpretare a habitatelor Natura 2000 din România, Risorprint, Cluj-Napoca, 101. (in Romanian)

13. Georgescu C. C., 1952 - Familia Betulaceae, in Flora Republicii Populare Române, I, Săvulescu T., 189-217, Edit. Academiei Române, Bucureşti. (in Romanian)

14. Ielenicz M., 1999 - Dealurile şi podişurile României, Edit. Fundaţiei „România de Mâine”, Bucureşti, ISBN 973-582-127-1, 244. (in Romanian)

15. Oberdorfer E. (Herausgeber/ed.), 1992 - Süddeutsche Pflanzengesellschaften, IV, Wälder und Gebüsche, A, Textband, Gustav Fischér Verlag Jena - Stuttgart - New York, 282. (in German)

16. Oberdorfer E., 2002 - Pflanzensoziologische Exkursionsflora für Deutschland und angrenzende Gebiete, 8, Auflage, Eugen Ulmer GmbH and Co, Stuttgart, 1051. (in German)

17. Oprea A., 2005 - Lista critică a plantelor vasculare din România, Edit. Universității Alexandru Ioan Cuza Iași, 667. (in Romanian)

18. Posea G., et al., 1983 - Enciclopedia Geografică a României (in Romanian), Edit. Ştiinţifică şi Enciclopedică, Bucureşti. (in Romanian)

19. Roşu, A., 1980 - Geografia Fizică a României, Edit. Didactică şi Pedagogică, Bucureşti, 234. (in Romanian)

20. Sanda V., Öllerer K. and Burescu P., 2008 - Fitocenozele din România, Sintaxonomie, structură și evoluție, Edit. Ars Docendi, Universitatea din București, 570. (in Romanian)

21. Schwabe A., 1985 - Monographie Alnus incana-reicher Waldgesellschaften in Europa, Variabilität und Ähnlichkeiten einer azonal verbreiteten Gesellschaftsgruppe. Phytocoenologia, 13, 197-302, Stuttgart, Braunschweig. (in German) 
22. Sârbu I., Ştefan N. and Oprea A., 2013 - Plante vasculare din România. Determinator ilustrat de teren, Edit. Victor B. Victor, Bucureşti, 1231. (in Romanian)

23. Mountford O. J. and Akeroyd J. R., 2005 - A biodiversity assessment of the Saxon Villages region of Transylvania (Romania), Transylvanian Review of Systematical and Ecological Research, 2, The Târnava River Basin, 31-42. 